\title{
УДК 004.42
}

О. А. Никитюк ${ }^{1}$, д.с.-г.Н., В. В. Новіков ${ }^{2}$, к.т.н., В. К. Домницька ${ }^{2}$

${ }^{1}$ Національний медичний університет ім. О. О. Богомольия, м. Київ

${ }^{2}$ Інститут підвищення кваліфікації фахівців в галузі технічного регулювання та споживчої політики Одеської державної академії технічного регулювання та якості, м. Київ

\section{СУЧАСНИЙ ПІДХІД ДО ВИКОНАННЯ ВИМОГ ДСТУ ЕN ISO 15189:2015 СТОСОВНО НЕОБХІДНОСТІ ВЕРИФІКАЦІї ТА ВАЛІДАЦІЇ МЕТОДИК ДОСЛІДЖЕНЬ В МЕДИЧНИХ ЛАБОРАТОРІЯХ}

У роботі запропоновано варіант підходу до виконання вимог стандарту ДСТУ EN ISO 15189:2015 [1] стосовно необхідності верифікації та валідації методик досліджень в клініко-діагностичних (медичних) лабораторіях, що трунтується на використанні програмного продукту «автоматизована інформаційна система в лабораторії».

Ключові слова: валідація, верифікаиія, автоматизачія, компетентність, лабораторія.

Метою роботи є обгрунтування необхідності впровадження в медичних лабораторіях автоматизації процесів планування, реєстрації та обчислень під час верифікації та валідації методів, що дозволяє відмовитися від паперових носіїв для реєстрації цих даних та суттєво зменшити витрати на виконання лабораторією вимог щодо верифікації методів стандарту [1].

Виконання технічних вимог стандарту [1] вимагає від лабораторії значних ресурсів і матеріальних витрат в т. ч. по проведенню валідації (оцінки придатності нестандартизованих методів) та верифікації (оцінки правильності використання) стандартизованих методів, що використовує лабораторія.

Автори в [2] обгрунтували можливість використання автоматизованих систем в лабораторіях випробувальних задля підвищення продуктивності праці та зменшення витрат на функціонування.

В лабораторіях медичних ми маємо ситуацію, коли оператори методик досліджень не мають відповідної базової математичної освіти, що вкрай ускладнює виконання ряду технічних вимог [1] взагалі.

Зважаючи на лібералізацію законодавства України в галузі метрології [3], конкурентні ринкові умови роботи випробувальних та калібрувальних лабораторій, розширення вимог до якості та безпеки об'єктів випробування, постійно розширюється сфера акредитації лабораторій та відповідно збільшується кількість методів, які необхідно валідувати та верифікувати.

Зрозуміло, що окрім проведення самого експерименту по валідації чи верифікації методу, технічні дані ще треба реєструвати, сам експеримент планувати, а результати реєструвати для того, щоб лабораторія була у змозі довести виконання вимог перед органом з акредитації - Національним агентством 3 акредитації України (НА-
АУ) та власними замовниками. При акредитації лабораторій, або при нагляді за акредитованими лабораторіями, експерти НААУ заповнюють спеціальну форму по оцінці методів [4], в якій мають зазначатися документовані докази валідації методу, або оцінювання спроможності лабораторії виконувати стандартизований метод (посилання на звіт про валідацію або результати оцінювання придатності). Стає очевидною необхідність розширення існуючого рішення використання новітніх інформаційних технологій у лабораторній практиці - автоматизованої інформаційної системи (AIC) «Лабораторія» [5] для виконання описаних вище задач, в т. ч. і задач формування готових звітів з верифікації та валідації методів. Звіти 3 верифікації методів $\epsilon$ не тільки підтвердженням правильності використовування методів, а й можуть використовуватись для таких складових системи якості лабораторії, як:

- підтвердження компетентності вже уповноваженого на дослідження персоналу та компетентності персоналу перед уповноваженням(стажерів);

- аналізування з боку керівництва;

- придбання послуг та ресурсів;

- контролювання якості результатів випробування.

В даній роботі викладена перша частина вирішення задачі - автоматизація верифікації методів.

\section{Методи}

Для оцінки правильності використання стандартних методів було вибрано 2 критерії оцінки оцінка відтворюваності (внутрішньолабораторної складової) та оцінка повторюваності (збіжності) i, відповідно, порівняння отриманих характеристик 3 вимогами методу, іншими словами - верифікація повторюваності та верифікація відтворювано- 
сті. Лабораторією може бути прийнято, що для оцінки правильності використання стандартного методу можна використовувати як один критерій, так і обидва одночасно, згідно, наприклад, з рекомендаціями Eurachem [6]

За оцінку відтворюваності та повторюваності прийнято стандартне відхилення та відносне стандартне відхилення результатів, що є загально прийнятою практикою, викладено, наприклад в ДСТУ ГОСТ ISO 5725-2 [7].

AIC «Лабораторія» вже формує журнал проміжних результатів, в т. ч. по результатам дослідження паралельних проб, тобто дані для розрахунку повторюваності вже $є$ в системі і їх не потрібно додатково вводити. У випадку оцінки відтворюваності, система використовує результати, що були отримані при випробуванні зразків, які зберігаються та стандартних зразків для реалізації методів внутрішньолабораторного забезпечення якості. Тобто, верифікація відтворюваності, так само як і верифікація повторюваності не вимагає від виконавця внесення будь-якої нової інформації щодо результатів випробувань в АIC «Лабораторія).

Для усереднення та оцінки загальної або середньої повторюваності система використовує формулу середнього квадратичного, що наведена, наприклад в ДСТУ ГОСТ ISO 5725-2 [7].

\section{Результати автоматизації}

Оскільки всі дані, необхідні для проведення верифікації, в AIC Лабораторія вносяться при записі результатів досліджень, формування звіту з верифікації проходить в самому спрощеному вигляді та вимагає мінімум ресурсів від лабораторії. Виконавець вибирає методику, вибирає розділ «Звіти 3 верифікації», де він може переглянути існуючі звіти з верифікації та створити нові.

Для формування нового звіту 3 верифікації виконавець вибирає період, за який системі слід брати дані $з$ журналів випробувань до звіту з верифікації та які результати брати - результати випробувань зразків замовника (тільки для оцінки повторюваності), чи результати випробувань стандартних зразків або зразків, що зберігаються (для оцінки повторюваності та відтворюваності). Система сама автоматично бере всі результати досліджень лабораторії по цій методиці за даний період часу та формує готовий до затвердження звіт з верифікації даної методики. Після цього, у керівника лабораторії з'являється нагадування, про необхідність затвердження даного звіту з верифікації через меню системи. Затверджений звіт з верифікації певної методики можна переглянути як через окреме меню, так і через перегляд методики.

Система автоматично ідентифікує звіт 3 верифікації, використовує результати досліджень 3 датами проведення та ідентифікацією відповідних зразків замовників лабораторії, що дозволяє повністю простежити ці результати, оцінює повторюваність по кожному зразку, загальну повторюваність, порівнює з межею повторюваності для цього методу та робить висновок про правильність використання методики виходячи із оцінки повторюваності.

Система автоматично ідентифікує також звіт 3 валідації, використовує результати випробувань 3 датами проведення та ідентифікацію відповідного стандартного зразку в лабораторії, що дозволяє забезпечити простежуваність результатів, оцінює повторюваність по кожному зразку, загальну повторюваність, порівнює 3 межею повторюваності для цього методу, оцінює відтворюваність (внутрішньолабораторну складову) та робить висновок про правильність використання методики виходячи із оцінки повторюваності та оцінки відтворюваності(внутрішньо лабораторну складову).

Звіти 3 верифікації формуються системою в форматі pdf та готовому до друку за формою, затвердженою лабораторією.

Блок «Верифікація методик», що $є$ умовною назвою автоматизації верифікації методів AIC «Лабораторія» успішно впроваджений в лабораторну практику ряду випробувальних лабораторій, в т. ч. ДП «Агмінтест» та ТОВ «Контрол Юніон Україна» (Control Union Ukraine), м. Одеса.

На момент подання статті до редакції, випробувальна лабораторія ДП «Агмінтест» сформувала 375 звітів з верифікації витративши саме на цей процес не більше 15 людино-годин разом 3 затвердженням цих звітів. Зрозуміло, що результати випробувань вже були записані в систему раніше. Формування цих самих звітів з верифікації «вручну» вимагало б від лабораторії мінімум на порядок більше часу, оскільки потрібно не лише формувати відповідні документи, збирати дані по відповідним журналам а і проводити обчислення. Зважаючи на такі результати впровадження, можна говорити про високу економічну ефективність запропонованого рішення для усіх видів лабораторіï.

\section{Висновки}

У статті розглянуто оригінальний варіант вирішення актуального технічного завдання - автоматизації процесів планування, реєстрації та обчислень під час верифікації методів в рамках вимог стандарту ДСТУ EN ISO 15189:2015. На прикладі впровадження в лабораторну практику випробувальної лабораторії ДП «Агмінтест» показана висока ефективність запропонованого рішення, що дозволило відмовитися від паперових носіїв для реєстрації даних верифікації та суттєво зменшити витрати на виконання лабораторією вимог щодо верифікації методів. 


\section{Список використаних джерел}

1. ДСТУ EN ISO 15189:2015. Медичні лабораторії. Вимоги до якості та компетентності. Затверджений наказом ДП «УкрНДНЦ» № 61 від 22.06.2015p.

2. Новіков В. М., Никитюк О. А., Новіков В. В. Основи компетентності лабораторій (ч.1). Навчальний посібник, - К.: Фавор, 2013. $243 \mathrm{c}$.

3. Закон України «Про метрологію та метрологічну діяльність» № 1314-VII від 05.07.2014 p: Відомості Верховної Ради (ВВР), 2014, № 30, ст.1008.

4. Система управління. Методика «Проведення оцінки лабораторії на місці» [Електронний ресурс]: / Національне агентство 3 акредитації України. - Методика. - 2014. - Режим доступу: http://naau.org.ua/wp-content/uploads/2014/04/M08.01.14_red_17_.pdf (дата звернення: 25.02.2016). - Назва $з$ екрану.

5. Новіков В. В. Автоматизована інформаційна система «Лабораторія» - реалізація новітніх інформаційних технологій в лабораторній практиці / В. Новіков // Стандартизація, сертифікація, якість. - 2014. - № 24. - С. 44 - 52.

6. B. Magnusson and U. Örnemark (eds.) Eurachem Guide: The Fitness for Purpose of Analytical Methods - A Laboratory Guide to Method Validation and Related Topics, (2nd ed. 2014). ISBN 978-91-87461-59-0.

7. Точність (правильність і прецизійність) методів та результатів вимірювання. Частина 2. Основний метод визначення повторюваності i відтворюваності стандартного методу вимірювання (ISO 5725-2:1994, IDT): ДСТУ ГОСТ ISO 57252:2005. - [чинний від 2006-07-01]. - К.: Держспоживстанадрт України, 2007. - 57 с. - (Національний стандарт України).

\section{Надійшла до редакиії 20.10.2016}

Рецензент: д.т.н., проф.. Коломієць Л. В., Одеська державна академія технічного регулювання та якості, м. Одеса

\section{А. А. Никитюк, д.с.-х.н., В. В. Новиков, к.т.н., В. К. Домницкая}

\section{СОВРЕМЕННЫЙ ПОДХОД К ВЫПОЛНЕНИЮ ТРЕБОВАНИЙДСТУ ЕN ISO 15189:2015 ОТНОСИТЕЛЬНО НЕОБХОДИМОСТИ ВЕРИФИКАЦИИ И ВАЛИДАЦИИ МЕТОДИК ИССЛЕДОВАНИЙ В МЕДИЦИНСКИХ ЛАБОРАТОРИЯХ}

В работе предложен вариант подхода к выполнению требований стандарта ДСТУ EN ISO 15189:2015 [1] о необходимости верификации и валидаџии методик исследований в клиникодиагностических (медициских) лабораториях, основаного на использовании программного продукта «автоматизированная информаџионная система в лаборатории».

Ключевые слова: валидация, верификаџия, автоматизация, компетентность, лаборатория.

O. A. Nykytyuk, DSc, V. V. Novikov, PhD, V. K. Domnitska

\section{THE MODERN APPROACH TO FULFILLING THE REQUIREMENTS OF DSTU EN ISO 15189:2015 ABOUT THE NEED FOR VERIFICATION AND VALIDATION OF RESEARCH METHODS IN MEDICAL LABORATORIES}

The paper offers a variant approach to implementing the requirements of the standard DSTU EN ISO 15189:2015 [1] about the need for verification and validation of research methods in clinical diagnostic (medical) laboratories, based on the use of the software "automated information system in the laboratory».

Keywords: validation, verification, automation, competence, laboratory. 